\title{
Potential Plastic Accumulation Zones in the Indian Coastal Seas
}

\author{
Sanitha K. Sivadas*, K. Ramu, Pravakar Mishra and Ramana Murthy MV \\ National Centre for Coastal Research (NCCR), Ministry of Earth Sciences (MoES), Government of India, Chennai, India
}

Keywords: plastic accumulation zones, biodiversity hotspots, coast, India, MPA

\section{INTRODUCTION}

Plastics account for $\sim 80 \%$ of the litter in many marine environments (Morales-Caselles et al., 2021) and, a suitable example of a transboundary problem. Several decades of waste mismanagement have made plastics ubiquitous in the global ecosystem and one of the largest growing environmental problems (Kershaw, 2016). Given the growing evidence of the threats caused by plastics and the projected alarming accumulation in the oceans, environmental managers are urgently pursuing sustainable solutions to reduce plastic.

One solution to plastic pollution is identifying the accumulation zones (i.e., hotspots of plastic accumulation). Accumulation zones are also critical for our long-term understanding of the dynamics of plastics in the marine system and identifying vulnerable ecosystems (Lebreton et al.,

OPEN ACCESS

Edited by:

Xiaoshou Liu,

Ocean University of China, China

Reviewed by:

Elena Balestri,

University of Pisa, Italy

Wenzhe Xu,

Tianjin University of Science and

Technology, China

*Correspondence:

Sanitha K. Sivadas

sanitha@nccr.gov.in

Specialty section:

This article was submitted to

Marine Pollution,

a section of the journal

Frontiers in Marine Science

Received: 31 August 2021 Accepted: 10 November 2021 Published: 30 November 2021

Citation:

Sivadas SK, Ramu K, Mishra P and MV RM (2021) Potential Plastic Accumulation Zones in the Indian

Coastal Seas.

Front. Mar. Sci. 8:768001. doi: 10.3389/fmars.2021.768001 2017). However, few reports have focused on this aspect of plastic research, particularly from the Indian coast. At the same time, there was a surge in marine plastic publications (80 articles); however, $65 \%$ of the study was from beaches. This article addressed this gap by identifying potential plastic accumulation zones along the Indian coast based on published literature. Studies in the field of oil dispersion, plankton connectivity, and marine safety recovery provide an opportunity to understand how oceanographic features may govern the transport of plastic in the ocean (Van Sebille et al., 2020).

\section{FACTORS AFFECTING THE DISTRIBUTION OF PLASTIC}

Once the plastics enter the ocean (e.g., rivers, land runoff, and atmospheric deposits) many factors including oceanographic processes, degradation (fragmentation, photooxidation, and biodegradation), and the characteristics of plastics (e.g., size, density, and surface area) influence its fate (Evangeliou et al., 2020; Wayman and Niemann, 2021). Buoyant polymers (e.g., polyethylene and low-density polystyrene) contribute to $74 \%$ of global plastic production. Positively buoyant plastics could be transported for long periods by wind and water currents until they are beached, trapped in different coastal habitats, sink due to loss of buoyancy, or biologically removed (Kvale et al., 2020; Wayman and Niemann, 2021). Negatively buoyant polymers (e.g., polystyrene and polyamide) are likely to sink to the seafloor.

Plastic shapes vary from elongated shapes (fibers and ropes) to shapes with a lower surface area to volume ratio (fragments and spheroids) (Ryan, 2015). Small-size plastics of all types are common in the open ocean because of low buoyancy, while large plastics accumulate in coastal waters (Morales-Caselles et al., 2021). Among the large plastic, fishing debris, including discarded and abandoned fishing gear in commercial fishing zones, constitute a high percentage of total litter and have a wide range of ecological and economic impacts (Richardson et al., 2019). While studies have reported substantial quantities of smaller plastics in the deep-sea sediment suggesting that this vast ecosystem is a hotspot for plastic accumulation and accounts for some of the "missing" plastics (Woodall et al., 2014; Kane and Clare, 2019). 


\section{THE DYNAMICS OF PLASTICS IN THE NORTH INDIAN OCEAN}

The Indian Ocean (IO) has unique oceanographic features, and how these conditions affect plastic transport and its interactions with biota is largely unknown and may differ from those in the other ocean. Moreover, Asian countries contribute significantly to plastics that enter the IO (Jambeck et al., 2015; Schmidt et al., 2017). However, there are huge uncertainties regarding the plastic generation and release, hence, warranting detailed investigations.

The Indian peninsula divides the North Indian Ocean (NIO) into the Arabian Sea (AS) and Bay of Bengal (BoB) basin (Supplementary Figure 1). The distinct geographic position of the NIO (landlocked to the north by Asian landmass) drives the strongest monsoonal winds, which reverses seasonally. The boundary currents along the east (East Indian Coastal CurrentsEICC) and west (West Indian Coastal Currents-WICC) coast of India also reverses seasonally and play a critical role in connecting the AS and BoB (Shankar et al., 2002; Schott et al., 2009). The IO connects to the Pacific Ocean through the Indonesia throughflow. Because the NIO is landlocked, there is no northern subtropical gyre and associated garbage patch, as observed in the Pacific and Atlantic Ocean (van der Mheen et al., 2019). Numerical modeling studies show a garbage patch forming in the BoB (Lebreton et al., 2012; van der Mheen et al., 2019) and corroborates with the study of Ryan (2013) and Li et al. (2021).

\section{COASTAL HABITATS-A TRAP FOR PLASTICS}

Coastal habitats are a major sink of marine plastic (Onink et al., 2021). The overall habitat complexity, such as the pneumatophore roots of mangroves, architectural complexity of seaweeds, seagrass, and coral reefs, facilitates plastic accumulation. Moreover, rocky and sandy shores may form either a final sink or represent temporary storage. The backshore can strand plastics in the vegetation and deeper sediments (Brennan et al., 2018).

The mangrove cover in India $(\sim 4,975$ sq. $\mathrm{km})$ includes the world's largest mangrove ecosystem, Sundarbans. The Gulf of Mannar, Gulf of Kachchh, Andaman and Nicobar, and Lakshadweep Islands are the major coral reef ecosystems of India. In addition, patchy and submerged reef systems are present along the coast (e.g., Grand Island and Angria Bank). Seagrass ecosystems (cover of $\sim 500 \mathrm{sq}$. $\mathrm{km}$ ) are located at isolated locations along the coast. Therefore, the diverse coastal habitats along the Indian coast (Figure 1) constitute potential trapping sites for plastics.

\section{POTENTIAL ACCUMULATION ZONES IN THE INDIAN SEAS}

The first potential accumulation zone along the Indian coast is the Marine Protected Area of Gulf of Mannar (GoM; Figure 1). The GoM is a highly-populated area, center for fishing and tourism, industrial belt, and religious significance.
Circulation in the GoM shows a distinct seasonal variation. The currents become strong during the Southwest monsoon and flow from west to east, while the Northeast Monsoon and Spring Intermonsoon (March-May) ocean currents are relatively weak. As a result of the weak currents and subsurface barrier effect of the Palk Strait, there is a lack of strong mixing of GoM and the Palk Bay (north) waters (Rao et al., 2011; Jagadeesan et al., 2013). The limited southern flow of BoB water also implies the possibility of plastics getting trapped in this region. The fate of plastics in the GoM will depend upon the coastal currents and characteristics of plastic. Floating plastics may be transported out of GoM during the southwest monsoon period. However, most plastics are highly likely to be retained due to the weak circulation, shallow depth, subsurface barrier effect, and diverse habitat. Higher microplastics in the coral reef and seagrass sites than the nearshore locations in the Rameswaram Island confirms the sedimentation of plastics in the region (Jeyasanta et al., 2020a). Beach plastics surveys from the area confirm multiple sources of litter (Jeyasanta et al., 2020b). The presence of foreign litter indicates that along with local sources, currents and circulation also plays an important role in plastic accumulation in the GoM (Ganesapandian et al., 2011).

The Gulf of Kachchh (GoK) and the Gulf of Khambhat $(\mathrm{GoKB})$ in Gujarat are also potential plastic accumulation sites. The GoK and GoKB are two highly energetic, macrotidal systems of the northeastern Arabian Sea (Babu et al., 2005). The GoK shows complex features of a macrotidal region, marked by shoals, channels, inlets, creeks, and islands. Sediment routing studies observed that the Indus River, Kachchh mainland coastal rivers, and Saurashtra peninsular rivers are the primary sediment sources to the Gulf (Prizomwala et al., 2014). The Indus River is among the top ten rivers that contribute to the continental plastic waste to the ocean (Schmidt et al., 2017). Studies based on fish larvae (Babu et al., 2005; George et al., 2011) and oil spill models (Kankara and Subramanian, 2007) indicate the redistribution of larvae and oil within the GoK. The GoKB is characterized by a funnel-shaped indentation, shallow depth (maximum $30 \mathrm{~m}$ ), and a large tidal flat. The Lagrangian modeling studies showed that the particles released into the Gulf do not leave the system except for a few particles from the south of the region, suggesting restricted water-mass exchange between the Gulf and the AS (Mitra et al., 2020). Gujarat accounts for around 65\% of the total plastic production of India. Therefore, the potential of a generation of high plastics waste and the longer residence times of floating particles due to the gulf's local oceanography and coastal geomorphology makes the area a potential plastic accumulation zone. Due to the slow oceanography flushing, semi-enclosed seas are potential sites for trapping plastics, as confirmed from studies in other regions (Cózar et al., 2015; Li et al., 2018; Sharma et al., 2021).

The islands (Andaman and Nicobar and Lakshadweep) are biodiversity hotspot regions of India. However, the island is becoming a hotspot for litter from local sources and neighboring countries (Dharani et al., 2003; Kaviarasan et al., 2020). The coastal circulation around the Andaman and Nicobar is primarily driven by equatorial forcing, with the local winds forcing a weak sea-level signal along the continental boundaries and around the 


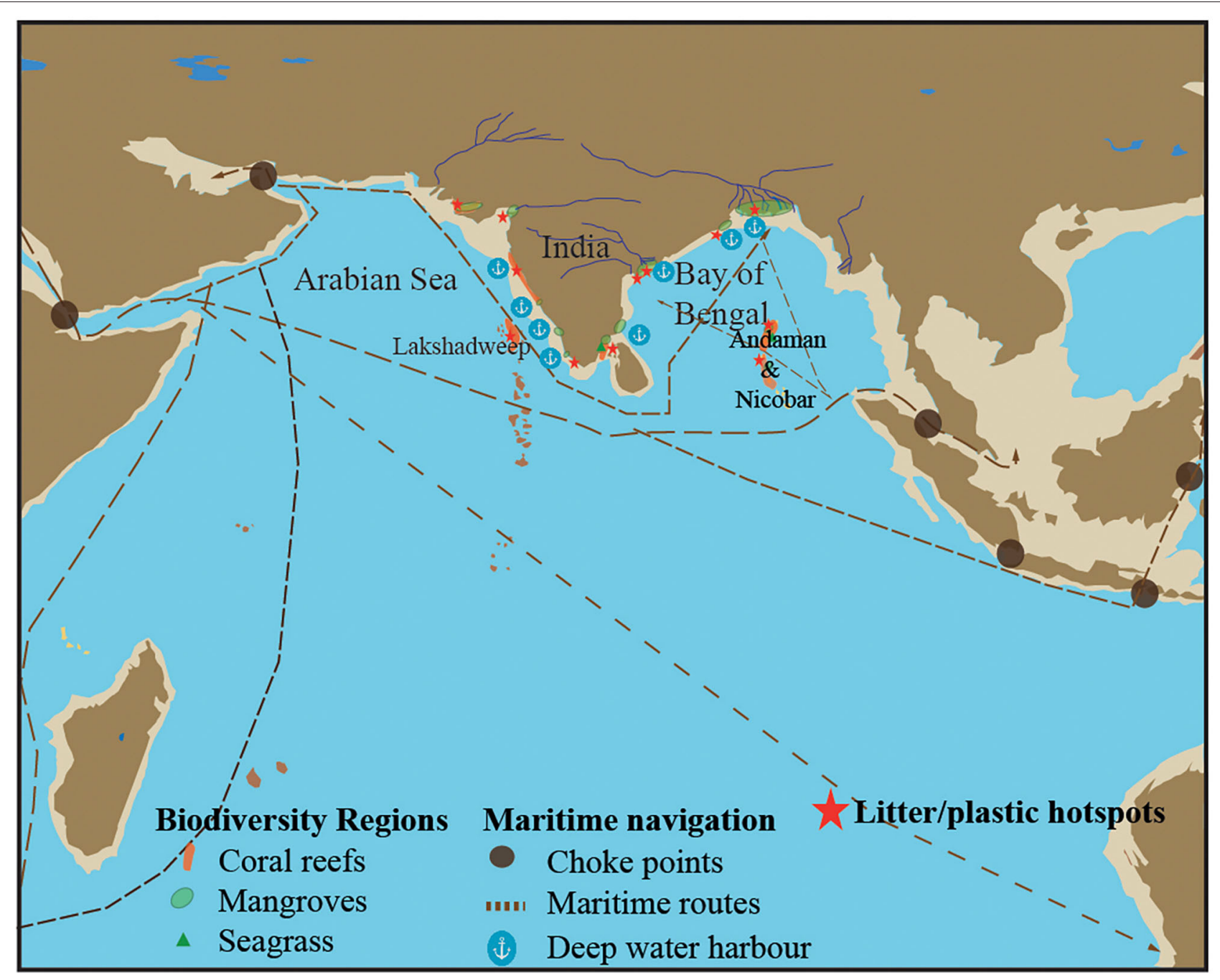

FIGURE 1 | Map of India showing important biodiversity regions, maritime routes, and potential plastic accumulation zones.

islands (Chatterjee et al., 2017). Generally, the surface circulation follows the seasonal reversing of currents observed in the IO; however, oceanographic features may be more complex due to the regions' topography. The islands also have a wide range of habitats (coral reef, mangroves, seagrass) and are influenced by four rivers (Ganga, Brahmaputra, Irrawaddy, and Salween) that show strong seasonal variability in the discharge rate. Multiple sources of plastic pollution, complex oceanographic features, and diverse habitats make the islands a potential plastic accumulation zone. Remote islands need to be considered to understand the dynamics of plastic as litter was also reported from many islands of the IO (Duhec et al., 2015; Bouwman et al., 2016; Imhof et al., 2017; Dunlop et al., 2020).

In addition, fronts (coastal fronts, river plumes, upwelling fronts, shelf-sea tidal fronts, shelf breakfronts, and fronts formed through interaction between flow and topography) can influence the transport of plastics (Hinojosa et al., 2011; Maximenko et al., 2012; Ribic et al., 2012; Pattiaratchi et al., 2021). Coastal fronts have a higher concentration of plastics than the surrounding waters (Pattiaratchi et al., 2021). The west coast of India is characterized by upwelling during the southwest monsoon and downwelling during the northeast monsoon (Rao et al., 2008). Compared to the west, the upwelling along the east coast is mild and confined close to the coast (Murty and Varadachari, 1968; Shetye et al., 1991). Coastal fronts and upwelling regions are important nurseries and foraging grounds. The upwelling of cold, nutrient-rich bottom waters and runoff generate high primary productivity that forms abundant high-quality food for the larvae. However, along with nutrients, riverine runoff also carries pollutants, including plastics, to the coastal system. Since the fronts are also sites for accumulating buoyant particles, it forms a potential site for higher interaction between biota and plastics. Plastics may be temporarily removed from the water column due to ingestion or aggregating in organic materials and sink to the seafloor.

Five of the world's 50 largest rivers discharge into the BoB (Sengupta et al., 2006). Except for the Indus, Narmada, and Tapti, runoff into the AS is mostly from minor seasonal rivers. 
Meijer et al. (2021) highlighted that relatively small polluted river basins contribute proportionally more compared to large river basins with equal amounts of mismanaged plastic waste generation within the river basins. Furthermore, small urban rivers are among the most polluting. India was the second-largest contributor to mismanaged plastic in the ocean (Meijer et al., 2021). The Ganges-Brahmaputra ranked sixth among the 10 topranked rivers transporting the highest plastic loads to the sea (Schmidt et al., 2017). Therefore, in terms of large and small polluting rivers, the Indian rivers may significantly contribute to ocean plastic pollution.

The Lagrangian particle tracking simulation of plastics indicates that under the influence of the reversing monsoonal currents, plastics move back and forth between the AS and the BoB (Van Der Mheen et al., 2020). As a result, a large number of particles are present in the AS during the Northeast monsoon (December to February), while during the Southwest Monsoon (June-September), particles are higher in the BoB (Van Der Mheen et al., 2020). However, the particles are present yearround in the BoB, probably due to the annual mean eastward flow in the equatorial region and the anti-cyclonic and cyclonic gyres that develop throughout the year (Paul et al., 2009; Van Der Mheen et al., 2020). Li et al. (2021) also concluded that the $\mathrm{BoB}$ is a potential microplastic hotspot as it receives massive input of land-based plastics and the presence of multiscale recirculation gyres.

Although the coastal currents connect the water masses of the AS and the BoB, they show a spatiotemporal variability (Durand et al., 2009; Amol et al., 2012; Mukherjee et al., 2014). The EICC is highly discontinuous and forms re-circulating loops (Durand et al., 2009). On the other hand, although WICC shows an equatorial flow during SWM, the overall flow along the south $\left(7^{\circ} \mathrm{N}\right)$ is poleward while it weakens toward the north of $20^{\circ} \mathrm{N}$ (Amol et al., 2012). This could probably retain more plastics toward the southwest coast of India. Robin et al. (2020) observed an increase in abundance from north to south of the Kerala coast.

Most plastic entering the NIO is likely to end up on the coastline within a few years, and some cross into the southern hemisphere of the IO (Van Der Mheen et al., 2020). However, plastic litter abundance on the Indian coast (Kaladharan et al., 2017; Goswami et al., 2020) is lower than in other areas (e.g., Vianello et al., 2013; Maes et al., 2017). Therefore, there is a considerable disparity between the estimated plastic waste entering the NIO and the amount recorded. A low abundance of plastics could also be due to the relatively limited studies or that various processes are at play that removes or transport the debris from the source.

Maritime and navigation activities are also important sources and areas of plastic accumulation. Since the IO is one of the busiest international maritime transportation routes and neighbors some of the largest plastic polluters (e.g., China,
Indonesia, and Sri Lanka) (Jambeck et al., 2015), shipping-related debris could be another important source of plastics to the Indian coast. Plastics of foreign origin are reported in India (Dharani et al., 2003; Ganesapandian et al., 2011) and vice versa. Therefore, the Indian seas, as an important navigation route, warrant the close analysis of these zones as a potential accumulation area of plastics.

\section{CONCLUSION AND WAY FORWARD}

The Government of India has taken several concrete initiatives to combat plastic pollution. These efforts will also contribute to global commitment, such as UN SDG 14. Hence, improved knowledge, sharing of information, and best practices are central to achieving these targets. Identifying plastic accumulation zones is one of the key tools to understand marine plastic dynamics. We propose the following research directions to improve the understanding of accumulation zones:

- Mapping the distribution of marine plastics based on in situ sample collection, citizen science, or the latest scientific tools.

- Modeling studies to confirm the identified accumulation zones and identify additional zones that will help to develop an effective plastic removal program.

- Developing a platform to support the integration and the analysis of all monitoring data.

- Harmonizing the monitoring protocols that will allow comparison.

- Promoting detailed studies on smaller polluting rivers to develop removal strategies, as removing litter from smaller rivers will be more practical than larger river basins.

\section{AUTHOR CONTRIBUTIONS}

SS: conceptualization, visualization, and writing-original draft. KR: supervision and writing-review and editing. PM: writing-review and editing. RM: project administration. All authors contributed to the article and approved the submitted version.

\section{ACKNOWLEDGMENTS}

The authors are thankful to the Ministry of Earth Sciences, Govt. of India, for implementing the Marine Litter and Microplastics Project at the National Centre for Coastal Research (NCCR), Chennai.

\section{SUPPLEMENTARY MATERIAL}

The Supplementary Material for this article can be found online at: https://www.frontiersin.org/articles/10.3389/fmars. 2021.768001/full\#supplementary-material 


\section{REFERENCES}

Amol, P., Shankar, D., Aparna, S. G., Shenoi, S. S. C., Fernando, V., Shetye, S. R., et al. (2012). Observational evidence from direct current measurements for propagation of remotely forced waves on the shelf off the west coast of India. J. Geophys. Res. Ocean. 117, 1-15. doi: 10.1029/2011JC007606

Babu, M. T., Vethamony, P., and Desa, E. (2005). Modelling tide-driven currents and residual eddies in the Gulf of Kachchh and their seasonal variability: a marine environmental planning perspective. Ecol. Modell. 184, 299-312. doi: 10.1016/j.ecolmodel.2004.10.013

Bouwman, H., Evans, S. W., Cole, N., Choong Kwet Yive, N. S., and Kylin, H. (2016). The flip-or-flop boutique: marine debris on the shores of St Brandon's rock, an isolated tropical atoll in the Indian Ocean. Mar. Environ. Res. 114, 58-64. doi: 10.1016/j.marenvres.2015.12.013

Brennan, E., Wilcox, C., and Hardesty, B. D. (2018). Connecting flux, deposition and resuspension in coastal debris surveys. Sci. Total Environ. 644, 1019-1026. doi: 10.1016/j.scitotenv.2018.06.352

Chatterjee, A., Shankar, D., McCreary, J., Vinayachandran, P. N., and Mukherjee, A. (2017). Dynamics of Andaman Sea circulation and its role in connecting the equatorial Indian Ocean to the Bay of Bengal. JGR Ocean 122, 3200-3218. doi: 10.1002/2016JC012300

Cózar, A., Sanz-Martín, M., Martí, E., González-Gordillo, J. I., Ubeda, B., Gálvez, J. Á., et al. (2015). Plastic accumulation in the mediterranean sea. PLoS ONE 10:e0121762. doi: 10.1371/journal.pone.0121762

Dharani, G., Abdul Nazar, A. K., Venkatesan, R., and Ravindran, M. (2003). Marine debris in Great Nicobar. Curr. Sci. 85, 574-575. Available online at: https:// www.jstor.org/stable/24109089

Duhec, A. V., Jeanne, R. F., Maximenko, N., and Hafner, J. (2015). Composition and potential origin of marine debris stranded in the Western Indian Ocean on remote Alphonse Island, Seychelles. Mar. Pollut. Bull. 96, 76-86. doi: 10.1016/j.marpolbul.2015.05.042

Dunlop, S. W., Dunlop, B. J., and Brown, M. (2020). Plastic pollution in paradise: daily accumulation rates of marine litter on Cousine Island, Seychelles. Mar. Pollut. Bull. 151:110803. doi: 10.1016/j.marpolbul.2019.110803

Durand, F., Shankar, D., Birol, F., and Shenoi, S. S. C. (2009). Spatiotemporal structure of the East India Coastal Current from satellite altimetry. J. Geophys. Res. Ocean. 114, 1-18. doi: 10.1029/2008JC004807

Evangeliou, N., Grythe, H., Klimont, Z., Heyes, C., Eckhardt, S., Lopez-Aparicio, S., et al. (2020). Atmospheric transport is a major pathway of microplastics to remote regions. Nat. Commun. 11:3381. doi: 10.1038/s41467-020-17201-9

Ganesapandian, S., Manikandan, S., and Kumaraguru, A. K. (2011). Marine litter in the northern part of Gulf of Mannar, southeast coast of India. Res. J. Environ. Sci. 5, 471-478. doi: 10.3923/rjes.2011.471.478

George, G., Vethamony, P., Sudheesh, K., and Babu, M. T. (2011). Fish larval transport in a macro-tidal regime: Gulf of Kachchh, west coast of India. Fish. Res. 110, 160-169. doi: 10.1016/j.fishres.2011.04.002

Goswami, P., Vinithkumar, N. V., and Dharani, G. (2020). First evidence of microplastics bioaccumulation by marine organisms in the Port Blair Bay, Andaman Islands. Mar. Pollut. Bull. 155:111163. doi: 10.1016/j.marpolbul.2020.111163

Hinojosa, I. A., Rivadeneira, M. M., and Thiel, M. (2011). Temporal and spatial distribution of floating objects in coastal waters of central-southern Chile and Patagonian fjords. Cont. Shelf Res. 31, 172-186. doi: 10.1016/j.csr.2010.04.013

Imhof, H. K., Sigl, R., Brauer, E., Feyl, S., Giesemann, P., Klink, S., et al. (2017). Spatial and temporal variation of macro-, meso- and microplastic abundance on a remote coral island of the Maldives, Indian Ocean. Mar. Pollut. Bull. 116, 340-347. doi: 10.1016/j.marpolbul.2017.01.010

Jagadeesan, L., Jyothibabu, R., Anjusha, A., Mohan, A. P., Madhu, N. V., Muraleedharan, K. R., et al. (2013). Ocean currents structuring the mesozooplankton in the Gulf of Mannar and the Palk Bay, southeast coast of India. Prog. Oceanogr. 110, 27-48. doi: 10.1016/j.pocean.2012.12.002

Jambeck, J. R., Geyer, R., Wilcox, C., Siegler, T. R., Perryman, M., Andrady, A., et al. (2015). Plastic waste inputs from land into the ocean. Science 347, 768. doi: $10.1126 /$ science. 1260352

Jeyasanta, K. I., Patterson, J., Grimsditch, G., and Edward Patterson, J. (2020a). Occurrence and characteristics of microplastics in the coral reef, sea grass and near shore habitats of Rameswaram Island, India. Mar. Pollut. Bull. 160:111674. doi: 10.1016/j.marpolbul.2020.111674
Jeyasanta, K. I., Sathish, N., Patterson, J., and Patterson Edward, J. K. (2020b). Macro-, meso- and microplastic debris in the beaches of Tuticorin district, Southeast coast of India. Mar. Pollut. Bull. 154:111055. doi: 10.1016/j.marpolbul.2020.111055

Kaladharan, P., Vijayakumaran, K., Singh, V. V., Prema, D., Asha, P. S., Sulochanan, B., et al. (2017). Prevalence of marine litter along the Indian beaches: a preliminary account on its status and composition. J. Mar. Biol. Assoc. India 59, 19-24. doi: 10.6024/jmbai.2017.59.1.1953-03

Kane, I. A., and Clare, M. A. (2019). Dispersion, accumulation, and the ultimate fate of microplastics in deep-marine environments: a review and future directions. Front. Earth Sci. 7:80. doi: 10.3389/feart.2019.00080

Kankara, R. S., and Subramanian, B. R. (2007). Oil spill sensitivity analysis and risk assessment for Gulf of Kachchh, India, using integrated modeling. J. Coast. Res. 23, 1251-1258. doi: 10.2112/04-0362.1

Kaviarasan, T., Naik, S., Sivadas, S. K., Dhineka, K., Sambandam, M., Sivyer, D., et al. (2020). Assessment of litter in the remote beaches of Lakshadweep Islands, Arabian Sea. Mar. Pollut. Bull. 161:111760. doi: 10.1016/j.marpolbul.2020.111760

Kershaw, P. J. (2016). Marine Plastic Debris and Microplastics Global Lessons and Research to Inspire Action and Guide Policy Change. United Nations Environment Programme. Available online at: https://wedocs.unep.org/20.500. $11822 / 7720$

Kvale, K., Prowe, A. E. F., Chien, C. T., Landolfi, A., and Oschlies, A. (2020). The global biological microplastic particle sink. Sci. Rep. 10, 1-12. doi: 10.1038/s41598-020-72898-4

Lebreton, L. C. M., Greer, S. D., and Borrero, J. C. (2012). Numerical modelling of floating debris in the world's oceans. Mar. Pollut. Bull. 64, 653-661. doi: 10.1016/j.marpolbul.2011.10.027

Lebreton, L. C. M., Van Der Zwet, J., Damsteeg, J. W., Slat, B., Andrady, A., and Reisser, J. (2017). River plastic emissions to the world's oceans. Nat. Commun. 8:15611. doi: $10.1038 /$ ncomms 15611

Li, C., Wang, X., Liu, K., Zhu, L., Wei, N., Zong, C., et al. (2021). Pelagic microplastics in surface water of the Eastern Indian Ocean during monsoon transition period: abundance, distribution, and characteristics. Sci. Total Environ. 755:142629. doi: 10.1016/j.scitotenv.2020.142629

Li, Y., Wolanski, E., Dai, Z., Lambrechts, J., Tang, C., and Zhang, H. (2018). Trapping of plastics in semi-enclosed seas: insights from the Bohai Sea, China. Mar. Pollut. Bull. 137, 509-517. doi: 10.1016/j.marpolbul.2018.10.038

Maes, T., Van der Meulen, M. D., Devriese, L. I., Leslie, H. A., Huvet, A., Frère, L., et al. (2017). Microplastics baseline surveys at the water surface and in sediments of the North-East Atlantic. Front. Mar. Sci. 14:135. doi: $10.3389 /$ fmars.2017.00135

Maximenko, N., Hafner, J., and Niiler, P. (2012). Pathways of marine debris derived from trajectories of Lagrangian drifters. Mar. Pollut. Bull. 123, 1197-1232. doi: 10.1016/j.marpolbul.2011.04.016

Meijer, L. J. J., van Emmerik, T., van der Ent, R., Schmidt, C., and Lebreton, L. (2021). More than 1000 rivers account for $80 \%$ of global riverine plastic emissions into the ocean. Sci. Adv. 7:eaaz5803. doi: 10.1126/sciadv.aaz5803

Mitra, A., Sanil Kumar, V., and Naidu, V. S. (2020). Circulation in the Gulf of Khambhat-A Lagrangian perspective. J. Mar. Sci. Eng. 8:25. doi: $10.3390 /$ jmse 8010025

Morales-Caselles, C., Viejo, J., Martí, E., González-fernández, D., Pragnell-raasch, H., González-Gordillo, J. I., et al. (2021). An inshore-offshore sorting system revealed from global classification of ocean litter. Nat. Sustain. 4, 484-493. doi: 10.1038/s41893-021-00720-8

Mukherjee, A., Shankar, D., Fernando, V., Amol, P., Aparna, S. G., Fernandes, R., et al. (2014). Observed seasonal and intraseasonal variability of the East India coastal current on the continental slope. J. Earth Syst. Sci. 123, 1197-1232. doi: 10.1007/s12040-014-0471-7

Murty, C. S., and Varadachari, V. V. R. (1968). Upwelling along the east coast of India. Bull. Natl. Inst. Sci. India 38, 80-86.

Onink, V., Jongedijk, C. E., Hoffman, M. J., van Sebille, E., and Laufkötter, C. (2021). Global simulations of marine plastic transport show plastic trapping in coastal zones. Environ. Res. Lett. 16:064053. doi: 10.1088/1748-9326/a becbd

Pattiaratchi, C., van der Mheen, M., Schlundt, C., Narayanaswamy, B. E., Naidu, A. S., Sara, H., et al. (2021). Plastics in the Indian Ocean - sources, fate, distribution and impacts. Ocean Sci. [Preprint]. doi: 10.5194/os-2020-127 
Paul, S., Chakraborty, A., Pandey, P. C., Basu, S., Satsangi, S. K., and Ravichandran, M. (2009). Numerical simulation of Bay of Bengal circulation features from Ocean General Circulation Model. Mar. Geod. 32, 1-18. doi: 10.1080/01490410802661930

Prizomwala, S. P., Bhatt, N., and Basavaiah, N. (2014). Understanding the sediment routing system along the Gulf of Kachchh coast, western India: significance of small ephemeral rivers. J. Earth Syst. Sci. 123, 121-133. doi: 10.1007/s12040-013-0379-7

Rao, A. D., Joshi, M., and Ravichandran, M. (2008). Oceanic upwelling and downwelling processes in waters off the west coast of India. Ocean Dyn. 58, 213-226. doi: 10.1007/s10236-008-0147-4

Rao, R. R., Girishkumar, M. S., Ravichandran, M., Gopalakrishna, V. V., and Thadathil, P. (2011). Do cold, low salinity waters pass through the IndoSri Lanka channel during winter? Int. J. Remote Sens. 32, 7383-7398. doi: 10.1080/01431161.2010.523728

Ribic, C. A., Sheavly, S. B., Rugg, D. J., and Erdmann, E. S. (2012). Trends in marine debris along the U.S. Pacific Coast and Hawai'i 1998-2007. Mar. Pollut. Bull.64, 994-1004. doi: 10.1016/j.marpolbul.2012.02.008

Richardson, K., Asmutis-Silvia, R., Drinkwin, J., Gilardi, K. V. K., Giskes, I., Jones, G., et al. (2019). Building evidence around ghost gear: global trends and analysis for sustainable solutions at scale. Mar. Pollut. Bull. 138, 222-229. doi: 10.1016/j.marpolbul.2018.11.031

Robin, R. S., Karthik, R., Purvaja, R., Ganguly, D., Anandavelu, I., Mugilarasan, M., et al. (2020). Holistic assessment of microplastics in various coastal environmental matrices, southwest coast of India. Sci. Total Environ. 703:134947. doi: 10.1016/j.scitotenv.2019.134947

Ryan, P. G. (2013). A simple technique for counting marine debris at sea reveals steep litter gradients between the Straits of Malacca and the Bay of Bengal. Mar. Pollut. Bull. 69, 128-136. doi: 10.1016/j.marpolbul.2013.01.016

Ryan, P. G. (2015). Does size and buoyancy affect the longdistance transport of floating debris? Environ. Res. Lett. 10:084019. doi: 10.1088/1748-9326/10/8/084019

Schmidt, C., Krauth, T., and Wagner, S. (2017). Export of plastic debris by rivers into the sea. Environ. Sci. Technol. 51, 12246-12253. doi: 10.1021/acs.est.7b02368

Schott, F. A., Xie, S. P., and McCreary, J. P. (2009). Indian Ocean circulation and climate variability. Rev. Geophys. 47:RG1002. doi: 10.1029/2007RG000245

Sengupta, D., Bharath Raj, G. N., and Shenoi, S. S. C. (2006). Surface freshwater from Bay of Bengal runoff and Indonesian Throughflow in the tropical Indian Ocean. Geophys. Res. Lett. 33:L22609. doi: 10.1029/2006GL027573

Shankar, D., Vinayachandran, P. N., and Unnikrishnan, A. S. (2002). The monsoon currents in the north Indian Ocean. Prog. Oceanogr. 52, 63-120. doi: 10.1016/S0079-6611(02)00024-1

Sharma, S., Sharma, V., and Chatterjee, S. (2021). Microplastics in the Mediterranean Sea: sources, pollution intensity, sea health, and regulatory policies. Front. Mar. Sci. 8:634934. doi: 10.3389/fmars.2021.6 34934

Shetye, S. R., Shenoi, S. S. C., Gouveia, A. D., Michael, G. S., Sundar, D., and Nampoothiri, G. (1991). Wind-driven coastal upwelling along the western boundary of the Bay of Bengal during the southwest monsoon. Cont. Shelf Res. 11, 1397-1408. doi: 10.1016/0278-4343(91)90042-5

van der Mheen, M., Pattiaratchi, C., and van Sebille, E. (2019). Role of Indian ocean dynamics on accumulation of buoyant debris. J. Geophys. Res. Ocean. 124, 2571-2590. doi: 10.1029/2018JC014806

Van Der Mheen, M., Van Sebille, E., and Pattiaratchi, C. (2020). Beaching patterns of plastic debris along the Indian Ocean rim. Ocean Sci. 16, 1317-1336. doi: 10.5194/os-16-1317-2020

Van Sebille, E., Aliani, S., Law, K. L., Maximenko, N., Alsina, J. M., Bagaev, A., et al. (2020). The physical oceanography of the transport of floating marine debris. Environ. Res. Lett. 15:023003. doi: 10.1088/1748-9326/ab6d7d

Vianello, A., Boldrin, A., Guerriero, P., Moschino, V., Rella, R., Sturaro, A., et al. (2013). Microplastic particles in sediments of Lagoon of Venice, Italy: first observations on occurrence, spatial patterns and identification. Estuar. Coast. Shelf Sci. 130, 54-61. doi: 10.1016/j.ecss.2013.03.022

Wayman, C., and Niemann, H. (2021). The fate of plastic in the ocean environment-a minireview. Environ. Sci. Process. Impacts 23, 198-212. doi: 10.1039/D0EM00446D

Woodall, L. C., Sanchez-Vidal, A., Canals, M., Paterson, G. L. J., Coppock, R., Sleight, V., et al. (2014). The deep sea is a major sink for microplastic debris. R. Soc. Open Sci. 1:140317. doi: 10.1098/rsos. 140317

Conflict of Interest: The authors declare that the research was conducted in the absence of any commercial or financial relationships that could be construed as a potential conflict of interest.

Publisher's Note: All claims expressed in this article are solely those of the authors and do not necessarily represent those of their affiliated organizations, or those of the publisher, the editors and the reviewers. Any product that may be evaluated in this article, or claim that may be made by its manufacturer, is not guaranteed or endorsed by the publisher.

Copyright (C) 2021 Sivadas, Ramu, Mishra and MV. This is an open-access article distributed under the terms of the Creative Commons Attribution License (CC BY). The use, distribution or reproduction in other forums is permitted, provided the original author(s) and the copyright owner(s) are credited and that the original publication in this journal is cited, in accordance with accepted academic practice. No use, distribution or reproduction is permitted which does not comply with these terms. 